\title{
State of Growth Barriers of SMEs in Pakistan: A Review based on Empirical and 'Theoretical Models
}

\author{
Fazeelat Masood ${ }^{1}$, Shuaib Soomro², Akhtiar Ali $^{3}$ \\ ${ }^{1} \mathrm{PhD}$ Scholar, Department of Management Sciences, Bahria University, Karachi \\ ${ }^{2} \mathrm{PhD}$ Scholar, Aix-Marseille Graduate School of Management, AIX province - France \\ ${ }^{3}$ Assistant Professor, Department of Management Sciences, Bahria University, Karachi
}

\section{A B S T R A C T}

Across the globe, SMEs are emerging as an unswerving accelerator of economic growth with a sizable contribution to job creation and customer need serving. Regardless of such support, the growth of SMEs in developing countries, with specific reference to Pakistan, is constrained. Surface facts pin down various underlying reasons for the inhibited economic growth of SMEs; however, veracity sticks to few, as principal wheelers of shackling prospects of small firm growth. Interestedly, this review paper is an attempt to provide the critical review of theoretical and empirical extent of literature on the state of SMEs in Pakistan. Findings of the review advise critical role of attitude towards technology, supplier relations, product innovation, human capital, regulatory requirements and access to finance in impeding smooth business progress and sustainable growth of SMEs in Pakistan. Findings of this review have implications for policymakers in devising, reforming and enforcing lucrative regulatory and legislative framework to stimulate entrepreneurial activities across manufacturing and nonmanufacturing sectors. In additions, it is also imperative for SBP and SMEDA to control access to finance issues by creating a regulatory environment with fair allocation of formal private and public institution funds to SMEs across all sectors of the economy. As for existing and potential entrepreneurs, this review paper has strived to sketch out situational analysis of critical dimensions which they need to consider while devising the strategy for business expansions with proactive and preventive measures against suggestible barriers to firm growth.

Keywords: Growth of SMEs, SMEDA, growth barriers, Entrepreneurial activity

\section{INTRODUCTION}

Subsequent to an elongated era of stagnation, Pakistan salvaged its economic progress with the emergence of Small and Medium-scale Enterprises (SMEs) in the late 1990s (Dasanayaka \& Sardana, 2015; Dar, Ahmed, \& Raziq, 2017). During this period, the government attempted to create a lucrative business environment by explicitly 
enacting SME policy through the establishment of Small and Medium Enterprises Development Authority (SMEDA) (Bhutta, Rana, \& Asad, 2008; Zafar \& Mustafa, 2017). Furthering economic role of SMEs, United Nations Industrial Development Organization (UNIDO) initiated Industrial Information Network (IIN) to stimulate entrepreneurial activities through trade associations and partnership in Pakistan (Dasanayaka \& Sardana, 2015). Pakistan is principally an SME-driven economy with $90 \%$ of all private enterprises registered as SMEs (Aziz, Hasnain, Awais, Shahzadi, \& Afzal, 2017); employing labour workforce for $80 \%$ of the non-agriculture sector and making 35\% value additions to manufacturing (SMEDA, 2007). Annually, SMEs contribute $30 \%-40 \%$ to GDP and $25 \%$ to manufactured-goods export with total export contributions amounting Rs. 140billion (SMEDA, 2007; Sherazi, Iqbal, Asif, Rehman, \& Shah, 2013; Afraz, Hussain, \& Khan, 2013; Imran, Hamid, \& Aziz, 2018). In Pakistan, major SME contributions are evident in industries that include wood and furniture, dairy and products, cotton weaving, jewellery, food and catering and metal products (Ali, Rashid, \& Khan, 2014; Dasanayaka \& Sardana, 2015). Point in focus, the role of SMEs as a catalyst for economic development; pins down the need to comprehend growth behaviour of small firms operating in Pakistan, which if neglected, may lead the country towards economic retard situation.

Earlier studies have suggested that SMEs remain on the verge of stoppage owing to considerable barricades impeding their growth rates in the long run due to an uneven blend of tangible and intangible resources (Carter \& Auken, 2006; Hussain, Farooq, \& Akhtar, 2012; Jebna \& Baharudin, 2013; OECD, 2014; Page \& Söderbom, 2015; Petković, Jäger, \& Sašić, 2016; Aziz et al., 2017). SME failure rates have been as high as $80 \%-90 \%$ in the initial years of business operations and such high rates of failure are unsustainable (Ullah, Naimi, \& Yusoff, 2016; Aziz et al., 2017).

In the last two decades, significant academic attention has been paid to gather theoretical and empirical evidence on the underlying causes of meagre success rates of SMEs in developing and developed economies (Daniel, Wilson, \& Myers, 2002; Jutla, Bodorik, \& Dhaliwal, 2002; Brown \& Lockett, 2004; Bari, Cheema, \& U1 Haque, 2005; 
Beck, Demirgüç-Kunt, \& Maksimovic, 2005; Bhutta et al., 2008; Hussain, Si, Xie, \& Wang, 2010; Ardic, Mylenko, \& Saltane, 2011; Ali et al., 2014; Dasanayaka \& Sardana, 2015; Bouazza, Ardjouman, \& Abada, 2015; Bilal, Khan, \& Akoorie, 2016; Marri, Gunasekaran, Gopang, Nebhwani, \& Soomro, 2017). Among common barriers SME growth is constrained by lack of innovation, scanty access to external credit, strict regulatory and legislative environment, old-fashioned production processes, unskilled labour and inadequate infrastructure (Bhutta et al., 2008; Bilal et al., 2016; Hyder \& Lussier, 2016; B. Ullah, Aziz, \& Yousaf, 2016). However, research inquiries on explaining barriers to the growth of Pakistani SMEs are limited in scope and implication. Given the significant economic value of small firms, it is necessary to evaluate growth barriers of SMEs in Pakistan. To be precise, this paper is an attempt to gather theoretic and empirical literature support on key barriers including attitude towards technology, product innovation, access to finance, relations with suppliers, human capital and regulatory requirements to the sustainable growth of SMEs in Pakistan.

\section{The methodology of Literature Extraction}

This paper attempted to study the extant literature that discusses the growth barriers of Pakistan based SMEs. To serve the purpose, secondary data sources including Science Direct, Emerald, Wiley and Taylor \& Francis and Google Scholar were accessed to collect published information (journal articles and research papers). Data searching was done using keywords that include the attitude of SME managers towards technology, SMEs and supplier relations, SMEs and product innovation, SMEs and human capital, SMEs access to finance. Then the potential material was selected through a three-step inclusion/exclusion criterion. Firstly, searched journals were filtered on the basis of the quality of content which was decided on basis of abstract reading. First preference was to seek and pick out impact factor and/or ABCD ranked journals. Secondly, articles from these journals were filtered on the basis of relevance to SMEs growth. Thirdly, relevant articles were further skimmed through on the basis of the time factor. A due care is given to include discussion based on the critical synthesis of the latest publication. 


\section{LITERATURE REVIEW}

Bilal et al. (2016) interestingly characterized SME growth in qualitative and quantitative terms. Qualitatively, SME growth is defined as product quality, customer perception of business and market position while quantitatively, SME growth has referred to sales revenues, business expansion, and value additions. Akinboade (2014) and Rodríguez \& Nieto (2016) provided similar views on determining parameters of small firm growth. Concerning SME growth, economic theory mainly emphasized the association between business size and growth. Thus conventional models have portrayed a positive association between the two variables while considering economies of scope and scale (Bilal et al., 2016). Contrary to expectations of orthodox views, prevailing economic theory based research fortified faster growth rate of SMEs relative to large size firms (Bilal et al., 2016). Likewise, when assessing growth strategies of SMEs, prospect theory has shed light on entrepreneurial behaviour and decision making under risk. This theory has advocated risky entrepreneurial behaviour in situations leading towards bleak business prospects (Parežanin, Jednak, \& Kragulj, 2014). Keeping these theories in perspective, Bilal et al. (2016) suggested that inefficient business practices related to cash handling, inventory management and increased costs of capital barricade SME growth.

Hussain et al. (2010) suggested a statistically significant role of external critical failure factors (CFFs) in the increased failure rate of SMEs. A critical contributor to these failures is inadequate access to financial aid or absence of easy-credit (See for example (Bari et al., 2005; Bhutta et al., 2008; Hyder \& Lussier, 2016; Dar et al., 2017). Small firms' access to financial institution credit facility is roughly around $14 \%$ (Hyder \& Lussier, 2016). The poor access is due to SMEs' limited ability to repay debts (Bari et al., 2005; Afraz et al., 2013; B. Ullah et al., 2016; Dar et al., 2017). The situation becomes grave since SMEs' ability to generate internal funds shrinks proportionate to the size of firms (Bilal et al., 2016).

The Globalization and technological advancement have necessitated the emergence of knowledge-based economies where intellectual capability is preferred over natural and physical resources (Khalique, Isa, \& Shaari, 2011; Khalique, Bontis, Shaari, 
\& Isa, 2015; Pathan, Tunio, Latif, Ahmed, \& Naich, 2018). Afraz et al. (2013) identified human capital (a component of intellectual capital) as a barrier to SME growth due to lack of investment in grooming labour skills, competencies, and experience. Hence, poor employee training and the shortage of skilled labour have hampered SME growth in Pakistan. According to Ali et al. (2014), SMEs play an imperative role in boosting the economy with pro-poor growth. In years with the increased output level of small-scale industries, they found the negative effect of SMEs' output on poverty levels in Pakistan. This research suggested a significant role of SMEs in creating jobs, alleviating poverty and accelerating economic growth (Ali et al., 2014).

The Country-specific and cross-country studies have been carried out in empirically testing obstacles and barriers to the business growth of SMEs. For example, Bilal et al. (2016) examined external, social environmental and institutional factors impeding the growth of SMEs based in China, India, and Pakistan (CIP). They applied Constraints to the Determinants of SMEs' Growth (CDSG) model to carry out OLS regression of data gathered on 1443 SMEs from the South East Asian region. In mediating role of tax rate and innovation, they concluded positive impact of external finance on Pakistani and Indian SMEs while this component was proven to be irrelevant in case of Chinese SMEs. Further, they found corruption, proficient workforce and infrastructure as significant obstacles to CIP based-SMEs' growth. To note the fact, Bilal et al. (2016) supplied empirical proof to claim potential growth hindrance for SMEs if they fail to manage proposed variables in an efficient manner.

In a statistical analysis of 651 surveyed SMEs, Bhutta et al. (2008) measured the association between SME health and owner characteristics. Their inquiry revealed the positive influence of academic qualification, techno-savvy skills, and social media practices of business owners on firm health. They concluded a consistent and significant role in technology usage and owner habits related to information collected in the success of SMEs (Bhutta et al., 2008). Additionally, less supportive government regulations, weak infrastructure, tax burden and lacking managerial skills are among the major causes of failure of small-scale enterprises (Bari et al., 2005; Hussain et al., 2010; Dar et al., 2017). 
Summing to the point, small firms have been playing a vital role in the economic development of Pakistan since the 1990s till-to-date. To recapitulate, SMEs have enhanced the economic competitiveness of Pakistan by accelerating GDP across sectors (majorly manufacturing), creating sizable jobs for the industrial sector and promoting social progress. Above literature review implies small size as an added advantage for SMEs in terms of their ability to swiftly respond to market conditions. In Pakistan, SMEs have grown at an accelerated pace while making additions to employment charts and economic competitiveness of the country. However, surprisingly high failure rates and incompetence of SMEs to progressively run typical business cycle has raised questions on its surface reality as a pliable economic driver; thereby, necessitating inquiry of SME growth. Hitherto, theoretical and empirical evidence has been established on the academic and non-academic significance of assessing SME growth and barriers to impede it. Thus, it is imperious to delve into aspects of each of six barriers to comprehend their expected role in shaping growth behaviour of SMEs. Therefore, the next section of review strives to explore a connection between each of the six barriers and SME growth in Pakistan.

\subsection{Attitude towards Technology and SME Growth}

The Attitude of a business owner is an internal factor to shape the growth of the business. Owners perceive the term 'growth' as a risk rather than an opportunity to explore. It implies that small firm owners' attitude towards growth is more likely to be driven by cost-benefit analysis (Falkner \& Hiebl, 2015; Saridakis, Lai, Muñoz Torres, \& Mohammed, 2017). In another research, Ghobakhloo, Hong, Sabouri, \& Zulkifli (2012) found the owner/manager's desire for growth as one of the key motivators behind SMEs' adoption of IT services.

The Research shows that small firms' attitude towards technology depicts their acceptance of and willingness to develop new knowledge as a source of advantage over competing firms. Firms' willingness to adopt new technology and to develop new skills can benefit it in terms of access to competitively increased numbers of customers (Jasra, Hunjra, Rehman, Azam, \& Khan, 2011). Flexibility and adaptability of SMEs to readily accept new ideas and approaches to gather and disseminate information, improve 
business-supplier and business-customer relations, enhance organizational capability, cut production and transaction costs and maintain quality check (Daniel et al., 2002; Krasniqi, 2007).

At the onset of globalization and knowledge-based economy, technology is a driving force for SME growth as it has immense potential to facilitate or encumber business growth (Martin \& Matlay, 2001; Swierczek \& Ha, 2003; Ghobakhloo et al., 2012; Pathan et al., 2017). However, SMEs slowly adopt technology due to globalization challenges and restricted market information access (MacGregor \& Vrazalic, 2005; Madrid-Guijarro, Garcia, \& Auken, 2009; Ghobakhloo et al., 2012; Hassan, Iqbal, Malik, \& Ahmad, 2017). Likewise, Bagh, Arif, Liaqat, \& Razzaq, (2017) stated that technological innovation and technological skills are critical to SME success; however, Jasra et al. (2011) opposed to the fact that high installation costs and capital requirements inhibit SMEs from technology acceptance.

The Adoption of technology has added advantages in terms of improved work productivity, lower costs, enriched revenues, and job creation (Ritchie \& Brindley, 2005; Jasra et al., 2011). Therefore, in the real world, SMEs' attitude towards technology is susceptible to varying internal (such as resource availability, managerial skills, scope) and external variables (such as competition, regulatory burden) (Hussin, King, \& Cragg, 2002; Pan \& Jang, 2008; Li, Lai, \& Wang, 2010; Selamat, Jaffar, \& Kadir, 2011; Seethamraju, 2015). For example, the model of technology acceptance (TAM) theorized external forces such as perceived ease of use and perceived utility as drivers of technology acceptance and usage (Selamat et al., 2011). In support, Igbaria, Zinatelli, Cragg, \& Cavaye (1997) found a direct impact of these two factors on the acceptance of personal computers by small firms. In another research, Teo (2001) found a strong association between technology usage and acceptance.

In response to changing technological trends and SMEs' adoption behaviour, researchers have found restricted progression levels with dawdling response rates (Jutla et al., 2002; Ritchie \& Brindley, 2005). For example, R\&D investments and set-up costs inclusive of human and financial capital are found to be among the lead causes of slow or delayed acceptance rate among SMEs (Love \& Roper, 2015). On the other hand, small 
firms' slow adoption rates are associated with knowledge deficiency, lack of technological expertise, and degree of technical complexity (Brown \& Lockett, 2004; Ritchie \& Brindley, 2005). In their findings, Brown \& Lockett (2004) reported the technological comfort rate of $79 \%$ SMEs to be very low. In developed economies, SMEs have stepped up the front-line of gearing economic ships through recessionary periods and abrupt market situations by deploying techno-savvy approach to business (Krasniqi, 2007; Khalique, 2011; Marri et al., 2017). Unlikely, technology adoption rates are yet to progress in developing economies, especially in Asian countries such as Pakistan. Noticeably, technology is an integral part of SME growth model as it not only expedites business innovation and productivity, but it also enhances SMEs' ability to transmute market opportunities into realized profits (Jasra et al., 2011).

In Pakistan, SMEs are clung to traditional models of business; hence, less adaptive and responsive to changing technologies (Jasra et al., 2011). Subsequently, SMEs continue to face survival threats due to inadequate technological know-how and technological readiness. SMEs have continuously reported stumpy business growth and in most cases, closure of business even before crossing the infant stage. Little or no adoption of changing technology is recognized as one of the major barriers to the sustainable growth of SMEs. Ahmed, Shahzad, Umar, \& Khilji (2010) viewed lack of training as a discouraging factor for employees to properly use software packages. In the research, they found small growth in the use of communication technology. In addition, poor business performances were witnessed as these small-scale enterprises lacked necessary skills required to update with interconnectivity and telecommunication services (Ahmed et al., 2010). Therefore in another research, Omer (2015) emphasized the adoption of changing technologies by SMEs. In his research, Omer (2015) has supported the need to utilize social media networking for entrepreneurs and small and mediumsized enterprises to adapt to changing technological trends. This research study has recognized e-commerce as an important and useful platform for carrying out commercial activities (Omer, 2015).

\subsection{Supplier Relations and SME Growth}

The concept of global production networks (GPNs) incepted with the surfacing 
phenomenon of deregulated economies, liberal trade, and outsourcing which pinpointed supplier as a value-added part of the supply chain (Lund-Thomsen, 2013; Egels-Zandén, 2017; Mahmood, Kouser, Hasan, \& Iqbal, 2017). GPNs' growing reliance on developing countries created prospects for SMEs as well and it led to SME integration in widespread GPNs (Knudsen, 2013; Egels-Zandén, 2017); however, existing GPN literature has suppressed the role of SMEs may be due to overshadowing of MNE (Johnsen, 2009; Egels-Zandén, 2017). Nonetheless, GPNs literature and other works such as a research conducted by Singh, Garg, \& Deshmukh (2009) portrayed the supply-side relationship of SMEs with larger firms; whereas, this section strives to explore the other side of supply chain i.e. SME-supplier relationship. Managing customer-supplier relationship is central to the concept of managing supply chain (Morrissey \& Pittaway, 2006; Matsoso \& Benedict, 2014) since suppliers are viewed as a valuable addition to firms' knowledge and innovation. For a small firm, a collaborative arrangement or partnership with the supplier is an indication of the expected increase in business growth (Beekman \& Robinson, 2004). This argument is backed with empirical evidence showing $10 \%$ annual growth increase for small firms that emphasized on building long-term relations with suppliers (Beekman \& Robinson, 2004). Good relations with suppliers have added benefits for SMEs in terms of easy access to resources (i.e. smooth supply of raw material, critical components) and the opportunity to learn (i.e. opportunity to be aware of changing market requirements (Beekman \& Robinson, 2004). In addition, a partnership with a supplier may also help solve credibility issues as such partnership is a sign of social recognition and improved credibility for small firms (Stuart, 2000; Beekman \& Robinson, 2004).

In small-scale enterprises, Ellegaard (2006) and Pressey, Winklhofer, \& Tzokas (2009) stated greater reliance on the maintenance of interpersonal relationships with suppliers as an external resource to considerable gains. Opposing large-scale firms, SMEs tend to engage in less formal supplier relations to be built on and nurtured by mutual trust factor. Maintenance of such personalized and less formal relationship is found to have considerable influence on the responsiveness of supplier (Handfield \& Bechtel, 2002). Matsoso \& Benedict (2014) analyzed negotiation power as a crucial factor for SMEs to 
benefit from the good customer-supplier relationship, the capability of SMEs to operate on Just-in-Time (JIT) approach is practically less desirable due to relatively small order size which hampers their negotiation power over suppliers.

The SMEs' approach towards managing supplier relations is not universal; hence, changes across countries; for example, Chinese firms put growing emphasis on resource utilization in an effective manner through relationship management (Singh et al., 2009); networking and clustering of supply chain activities bears fruits of improved supplier-customer relationships (Dasanayaka \& Sardana, 2015). Nichter \& Goldmark (2009) reported buyer-supplier vertical linkage as a facilitator of SME growth.

Unfortunately, research in this regard is limited in size and provides constrained view of supplier relations' tendency to shape SME growth in Pakistan. For example, in a cross-country analysis, a research has explored benefits of clustering in terms of location advantages (such as Sialkot and Faisalabad in Pakistan and Kanpur, Nagpur in India) leading to economic dimensions such as better recruitment and retention of skilled workers, access to market and improved infrastructure (Dasanayaka \& Sardana, 2015). Unfortunately, the success of these clusters is vulnerable to poor provisions of educational and technical facilities, technological obsolesce and limited focus on innovation. As result, SME performance and growth in these developing countries have been less promising. In the context of Pakistani SMEs, Rehman (2016) propounded network alliance and joint venture to have a positive influence on SME performance.

\subsection{Product Innovation and SME Growth}

In an economy, process or product innovation is increasingly highlighted as a favorable mean to mobilize domestic resources and to improve firm performance (Aksoy, 2017). In literature, the term 'innovativeness' is defined as a firm's tendency to shore up creativity and novelty which can be transformed into a new product (Halim, Ahmad, Ramayah, \& Hanifah, 2014). Alongside core functions, if a firm succeeds in facilitating innovative products and services then it is likely to capture enough share of the market to survive (Luoma-aho et al., 2012). In order to achieve any of the two types of innovation, it is imperative that firms concentrate investments in $R \& D$ activities. $R \& D$ investment enhances product innovation (Hall, Lotti, \& Mairesse, 2009). 
The researchers have propounded SMEs' ability to stimulate entrepreneurial activities with adaptability to market conditions (Nooteboom, 1994; Islam, Khan, Obaidullah, \& Alam, 2011). Contrasting to large size firms, limited resource position has inclined SMEs towards satisfying niche market needs. Therefore, SMEs are found to prefer product innovation over process innovation due to their relatively high saleable features (Verhees \& Meulenberg, 2004; Nieto \& Santamaría, 2010). This implies that innovation is a requisite for business success and long-run survival and its value even intensifies in the case of SMEs (Ebrahimi \& Mirbargkar, 2017). However, product innovation with petite care or no innovation at all is means with no ends. In the existing literature, little or no efforts have been made in determining the nature of the relationship between product innovation and small firm growth, especially in Pakistan.

\subsection{Access to Finance and SME Growth}

In any industry, access to finance is one of the requisites to be fulfilled prior to and during operationalizing business activities (Bari et al., 2005). Here, access to finance depicts ease, convenience, and access to use external finance either in form of a formal line of credit (from a bank) or government grants (from a public institution). Access to finance is integral to innovativeness and growth in small firms (EC, 2016; Hyder \& Lussier, 2016). Love \& Roper (2015) pinpointed finance access as a crucial factor in cash holding and liquidity performance of SMEs.

In a few research studies, small firms' access to external credit has been associated with bank size (Beck, Demirgüç-Kunt, \& Martinez Peria, 2008; Ardic et al., 2011). For instance, traditionally, research studies recognized small bank as the main source of the formal credit line (external) for SMEs due to less contingent, personalized and less formal requirements for accessing funds (Berger, Kashyap, \& Scalise, 1995; Weston \& Strahan, 1996; Beck et al., 2008). Banks in big size have complex application processing requirement hence they require more documents and prefer to work with established business rather than small emerging business (Ardic et al., 2011). Such requirements not only hamper small firms' access to finance but it also amplifies the related transaction and credit costs with high premiums on related risk (IFC, 2009). In consequence, SMEs located in under-developed economies are seen to show little 
reliance on external access to finance.

With the passage of time, the creation of micro-finance banks and international patron programs from ILO, World Bank, and ADB facilitated the business progress of SMEs in Pakistan (Bhutta et al., 2008). However, lending rates vary among small and large-scale firms mainly due to SMEs' constrained ability to negotiate credit terms with lenders (Dietrich, 2012).

The Lack of finance is a surmounting barrier to SME growth (Quader \& Abdullah, 2008; Ardic et al., 2011) as it prohibits a firm from acquiring new technology to improve productivity and competitiveness (Eniola \& Entebang, 2017). Finance manager's limited knowledge of finance is another constraint that hinders businesses to make good financial decisions necessary to grow and prosper (Jasra et al., 2011; Eniola \& Entebang, 2017).

Afraz et al. (2013) reported access to finance as the main constraint for $6 \%$ of firms (FY 2007) relative to 2\% (FY 2002); thus showing a decline in firms' access to external finance. In comparison with the average 30\% rate of South Asia, less than $15 \%$ firms in Pakistan choose external financing to fund working capital (Afraz et al., 2013). In Pakistan, Ahmad \& Alam (2015) proclaimed access to finance to be disproportionate and their argument is well based on fair access of the manufacturing sector to $50 \%$ of total credit lent to the private sector. The undue concentration of financial institutions' outstanding credit only to manufacturing sectors and sub-sectors is sufficed with its $13.5 \%$ contribution to all GDP along with $14.1 \%$ share to country employment (Ahmad $\&$ Alam, 2015). Ullah et al. (2016) recognized banking institutions' preference for credit relations as an underlying cause of small firms' poor access to finance. In their research, Ullah et al. (2016) reported Pakistani banks to maintain distant relations with SMEs; thereby lowering small firms' rate of credit base share. This claim is partially supported by Ahmad \& Alam (2015) in terms of the unduly growing flow of credit to manufacturing sector SMEs. In addition, small firms' access to finance is also constrained by poor financial literacy; which impedes small firm owners' ability to leverage lending schemes based on accounting statements. Despite SBP's measures to facilitate SME financing via micro-finance and e-credit, small firms' access to finance is 
hampered by the high cost of borrowing, corruption, and taxes (Dar et al., 2017). Therefore, as an alternative to external finance, significant numbers of SMEs choose to rely on vendor credit, camaraderie loans and personal savings (Dar et al., 2017).

\subsection{Human Capital and SME Growth}

The Human capital with proficiency and technical skills add value to the overall business worth as educated, skilled and competent workforces tend to improve productivity levels while unavailability of technically skilled workers can turn into a barrier for firm growth (Quader \& Abdullah, 2008; Khalique et al., 2011; Bouazza et al., 2015; Hashim, Osman, \& Alhabshi, 2015; Mubarik, Chandran, \& Devadason, 2018). Consonantly, Bouazza et al. (2015) showed a positive impact of human resource on the growth capabilities of SMEs. They also stated that increased human resource capacities lead to efficient productivity performance and augments employee motivation; thereby leading to a sustainable firm performance in the long run. Ullah et al. (2016) found the positive relationship of all sub-components of intellectual capital with the organizational performance of SMEs in Pakistani context; whereas, the degree of influence exerted by customer capital and human capital on organizational performance was statistically measured to be relatively weak.

The Development of human capital is crucial for business competitiveness as Singh et al. (2009) identified a high correlation between these two factors. In developing countries such as Pakistan, intellectual capital is considered as a critical success factor for SMEs. In the absence of appropriate human resource policy, recruitment and training of human resource are mainly governed by traditional approaches (Memon, Rohra, \& Lal, 2010). As a result, SME performance is restrained by lack of competencies, managerial and entrepreneurial skills to strategize firm's approach against changing competitive conditions (Khalique et al., 2011; Agostini, Nosella, \& Filippini, 2017). Another prevailing obstacle to SME growth is owner's limited or no academic qualification and poor business orientation, which in most cases, is found to be the driving force of SME failure (Akhtar, Raees, \& Rashid Salaria, 2011).

\subsection{Regulatory Requirements and SME Growth}

Regarding small firms, regulatory requirements are suggested to be government 
policies regarding registration of SMEs, their formal documentation and tax filing with the respective provincial government, government support programs for stimulating a number of new entrepreneurial activities in the country and trade regulations for small firms. This section also intends to gather literature support on assessing the role of SBP and SMEDA in enacting a fair policy of formal credit access to small firms across different economic sectors, if possible.

Regulatory requirements and the institutional environment have created an imbalanced competitive condition for micro and small enterprises. For instance, it has safeguarded resource efficient and established large firms in terms of subsidies while challenging small firms' capability of engaging in growth-oriented investments (Quader \& Abdullah, 2008; Hussain et al., 2010; Bouazza et al., 2015). These findings are backed by Beck et al. (2005) who advocated corruption, legal and financial challenges as a force to unduly limit the small-scale firm growth. Opposite to developed countries, SME performance in developing countries is significantly hampered by overburdening institutional and regulatory setting (World Bank, 2009). Growth prospects of SMEs diminish in a strict regulatory environment with unfair taxation system and poor support for business especially when such an unfavorable environment is accompanied with bribery and corruption (Hussain et al., 2010). Due to a small size and constrained business resources, it is difficult for SMEs to cope with pressures exerted by legislative and regulatory requirements (Khoumbati, Themistocleous, \& Irani, 2006; Melville \& Ramirez, 2008; Quader \& Abdullah, 2008).

In addition, regulatory requirements pertaining to accounts reporting is another challenge to SMEs due to their limited financial literacy; however, adoption of IFRS for regulatory purposes is prohibited to SMEs in Pakistan. Therefore, it is less likely to affect their performance and sustainable growth (Kaya \& Koch, 2015).

Kitching, Hart, \& Wilson (2015) proclaimed that regulatory effects on SME performance are in dire need to be thoroughly examined. The existing literature has surely built useful insights into regulatory effects; however, earlier stated findings partially examined and stated negative impact of so-called overburdening regulatory requirements on the performance of small firms. Prior researches claimed that SMEs 
suffer unduly from regulatory pressures mainly due to restricted resource capabilities; however, Kitching et al. (2015) marked it as a mistaken perception of regulatory impact. In fact, they found an interesting connection between the degree of regulatory impact and the way it is adapted by SME agents and their stakeholders such as customers, competitors, and suppliers. On a simple note, regulatory effects on a business performance and growth can only be accredited when these effects are both direct and indirect.

The academic research on regulatory barriers to SME growth in Pakistan is limited. According to Asian Development Bank report, enforcement of liberalized and structurally adjusted policies has led to declining growth of Pakistani SME sector. For example, small firms bear the relatively high cost of growth due to mounting regulatory compliance requirements such as pull-down characteristics of prevailing tariff structures (Bari et al., 2005). In addition, the inadequacy of government policies has led to poor performance of SME clusters resulting in high costs of market orientation and compromised quality of intermediary supplier of raw material and goods. Due to the absence of an appropriate regulatory framework, SMEs are suffering from a poor orientation of identifying and executing contracts that facilitate firm growth. In Pakistan, small firms' growth is predisposed to increasing regulatory compliance costs (such as General Sales Tax on export) pertaining to ambiguous rules, officials' privileged excessive discretion over grants and corruption (Bari et al., 2005; Dar et al., 2017). Consequently, escalating costs to comply with fiscal and non-fiscal regulations have overburdened growth of small firms (Bari et al., 2005). In short, SME growth is hampered by the prevailing design of regulatory and fiscal framework involving heavy transaction costs. Example of the notion can be supplied with dysfunctional procedures of income tax audit that impede SME growth (Bari et al., 2005).

\section{CONCLUSION}

In line with the theoretical and statistical evaluation conducted above, SMEs have become an inevitable economic driver of growth, job creation and social development in Pakistan. Such characteristic nature of SME growth calls for dedicated inquiries from academicians and practicians. Till to date, considerations have been paid 
to explore and assess performance, health, and progress of SMEs; however, trivial substantiation is provided on growth behaviour of SMEs in Pakistan. Correspondingly, this study has carried, first of its kind, research on providing a critical review of existing theoretical and empirical literature on the state of SMEs in Pakistan.

Findings of this research suggest a significant impact of factors attitude towards technology, supplier relations, product innovation, human capital, regulatory requirements and access to finance on the growth of SMEs in Pakistan. Based on the review of literature, owner's attitude towards technology and use of ICT tools is found to have positive association with firm performance (Ghobakhloo et al., 2012); likewise, it is suggestible to infer that attitude towards technology is expected to exhibit similarly significant influence on growth behaviour of SMEs in Pakistan (Ahmed et al., 2010; Jasra et al., 2011; Omer, 2015). The research also assesses evidence available on the importance of supplier relations for small firms. To note the fact, strengthening relations with suppliers are found to benefit firms in terms of increased credit supplies and augmented annual growth (Beekman \& Robinson, 2004; Ellegaard, 2006). Research also exhibits the imperative role of good supplier relations in establishing credit worth of firms, especially new entrepreneurs. This implies a positive role of supplier relations in improving the health and performance of SMEs (Nichter \& Goldmark, 2009; Rehman, 2016). Consonant with cross-country analysis, the inability of small firm owners to associate with an established and credible supplier and inadequate handling approach can have varying effects on growth. Since comparable conditions prevail in India, China and Pakistan; therefore, similar connectivity of supplier relationship with growth is expected to be observed in Pakistani firms.

In addition, the research reveals product innovation (in terms of novelty added to product features and design) as a source of competitive advantage for small firms (Islam et al., 2011; Luoma-aho et al., 2012). However, review results on the nature of the relationship between product innovation and SME growth are constrained with lack of dedicated efforts on inquiring the two factors together. On the other hand, it surely identifies scope for future researchers to investigate the degree of influence that product innovation may exert on the growth of small firms. Access to finance is found to be 
among lead barriers which are increasingly impeding growth behaviour of small firms in the SME sector (Quader \& Abdullah, 2008; Love \& Roper, 2015). The research has shown considerable accessibility issues for Pakistani SMEs; however, its magnitude of the impact is yet to be investigated (Hyder \& Lussier, 2016; Dar et al., 2017). Conforming to empirical understanding established through cross-country analysis, access to finance exercises considerable power overgrowth of small firms; therefore, findings of this research suggest a significant relationship between access to finance and SME growth in Pakistan.

The Human capital is another important factor to be considered when determining barriers to small firm growth because research findings show the tendency of human capital to shape growth behaviour of SMEs (Quader \& Abdullah, 2008; Bouazza et al., 2015). Conforming to empirical support from literature, it is concluded that lack of human competencies, reduced workforce efficiency and unavailability of skilled labour has a significant effect on small firms' ability to record sustainable growth. Additionally, elaborative review of the literature has revealed that slowdown in SME growth is due to limited support and facilitation offered by prevailing regulatory and legislative framework (Quader \& Abdullah, 2008; Hussain et al., 2010; Kitching et al., 2015). Burdening transaction costs, the uncooperative behaviour of respective officials, corruption and uneven allocation of access to formal credit (public and private institutions) has serious policy implications in Pakistan. Therefore, SBP and SMEDA are suggested to introduce policy reforms in order to stimulate fairly balanced formal credit flows to all sub-sectors of SMEs and to encourage entrepreneurial confidence by cutting back high compliance costs. In addition, awareness programs should be arranged at the national level to help SMEs identify key barriers and simultaneously improving policies to mitigate the risk associated with or remove barriers.

\section{REFERENCES}

Afraz, N., Hussain, S. T., \& Khan, U. (2013). Barriers to Growth of Small Firms in Pakistan: A Qualitative Assessment of Selected Light Engineering Industries. International Growth Centre (IGC) Working Paper, 2-60.

Agostini, L., Nosella, A., \& Filippini, R. (2017). Does intellectual capital allow improving innovation performance? A quantitative analysis in the SME context. Journal of Intellectual Capital, 18(2), 400-418. https://doi.org/10.1108/JIC-05-2016-0056 
Ahmad, I., \& Alam, K. (2015). Credit flows to Pakistan's manufacturing SME sector. The Lahore Journal of Economics, 20, 261-270.

Ahmed, I., Shahzad, A., Umar, M., \& Khilji, B. A. (2010). Information technology and SMEs in Pakistan. International Business Research, 3(4), 237.

Akhtar, S., Raees, R., \& Rashid Salaria, M. (2011). The Impact of Firm, Location, and Ownership Specific Factors on Foreign Market Performance of Pakistani SMEs. International Conference on Technology and Business Management, 51325521.

Akinboade, O. A. (2014). Regulation, SMEs' Growth and Performance in Cameroon's Central and Littoral Provinces' Manufacturing and Retail Sectors: Regulation, SMEs' Growth and Performance. African Development Review, 26(4), 597-609. https://doi.org/10.1111/1467-8268.12116

Aksoy, H. (2017). How do innovation culture, marketing innovation, and product innovation affect the market performance of small and medium-sized enterprises (SMEs)? Technology in Society, 51, 133-141. https://doi.org/10.1016/j.techsoc.2017.08.005

Ali, S., Rashid, H., \& Khan, M. A. (2014). The role of small and medium enterprises and poverty in Pakistan: An empirical analysis. Theoretical and Applied Economics, XXI (4 (593)), 67-80.

Ardic, O. P., Mylenko, N., \& Saltane, V. (2011). Small and medium enterprises: A crosscountry analysis with a new data set. Policy Research Working Paper, 2-31.

Attaran, M. (1997). CIM: Getting Set for Implementation. Industrial Management \& Data Systems, 97(1), 3-9. https://doi.org/10.1108/02635579710161287

Aw, B.-Y. (2002). Productivity dynamics of small and medium enterprises in Taiwan. Small Business Economics, 18(1/3), 69-84. https://doi.org/10.1023/A:1015125827427

Aziz, K., Hasnain, S. S. U., Awais, M., Shahzadi, I., \& Afzal, M. M. (2017). The Impact of Entrepreneurial Orientation on SME Performance in Pakistan: A Qualitative Analysis. International Journal of Engineering and Information Systems (IJEAIS), 1(8), 107-112.

Bagh, T., Arif, M., Liaqat, I., \& Razzaq, S. (2017). Impact of Financial Constraints on Growth and Development of Small and Medium Enterprises in Sialkot Pakistan. International Journal of Financial Markets, 2(4), 131-145.

Bari, F., Cheema, A., \& UI Haque, E. (2005). SME Development in Pakistan: Analyzing the Constraints to Growth. Asian Development Bank (ADB).

Beck, T., Demirgüç-Kunt, A., \& Maksimovic, V. (2005). Financial and legal constraints to growth: does firm size matter? The Journal of Finance, 60(1), 137-177. https://doi.org/10.1111/j.1540-6261.2005.00727.x

Beck, T., Demirgüç-Kunt, A., \& Martinez Peria, M. S. (2008). Bank financing for SMEs around the world: Drivers, obstacles, business models, and lending practices. Policy Research Working Paper, 4-43.

Beekman, A. V., \& Robinson, R. B. (2004). Supplier Partnerships and the Small, HighGrowth Firm: Selecting for Success. Journal of Small Business Management, 42(1), 59-77. https://doi.org/10.1111/j.1540-627X.2004.00097.x

Berger, A. N., Kashyap, A. K., \& Scalise, J. M. (1995). The Transformation of the U.S. Banking Industry: What a Long Strange Trip It's Been. Brookings Papers on Economic Activity, 2, 55-218.

Bhutta, M. K. S., Rana, A. I., \& Asad, U. (2008). Owner characteristics and health of SMEs in Pakistan. Journal of Small Business and Enterprise Development, 
15(1), 130-149. https://doi.org/10.1108/14626000810850883

Bilal, A. R., Khan, A. A., \& Akoorie, M. E. M. (2016). Constraints to growth: a cross country analysis of Chinese, Indian and Pakistani SMEs. Chinese Management Studies, 10(2), 365-386. https://doi.org/10.1108/CMS-06-2015-0127

Bouazza, A. B., Ardjouman, D., \& Abada, O. (2015). Establishing the factors affecting the growth of small and medium-sized enterprises in Algeria. American International Journal of Social Science, 4(2), 101-121.

Bridge, S., O'Neill, K., \& Cromie, S. (2003). Understanding enterprise, entrepreneurship and small business (2nd ed). Basingstoke: Palgrave.

Brown, D. H., \& Lockett, N. (2004). Potential of critical e-applications for engaging SMEs in e-business: a provider perspective. European Journal of Information Systems, 13(1), 21-34. https://doi.org/10.1057/palgrave.ejis.3000480

Carter, R., \& Auken, H. V. (2006). Small Firm Bankruptcy. Journal of Small Business Management, 44(4), 493-512. https://doi.org/10.1111/j.1540-627X.2006.00187.X

Daniel, E., Wilson, H., \& Myers, A. (2002). Adoption of E-Commerce by SMEs in the UK: Towards a Stage Model. International Small Business Journal, 20(3), 253-270. https://doi.org/10.1177/0266242602203002

Dar, M. S., Ahmed, S., \& Raziq, A. (2017). Small and Medium-Size Enterprises in Pakistan: Definition and Critical Issues. Pakistan Business Review, 19(1), 46-70.

Dasanayaka, S., \& Sardana, D. G. (2015). Development of Small and Medium Enterprises through Clusters and Networking: A Comparative Study of India, Pakistan and Sri Lanka. International Journal of Economics and Business Administration, 3(2), 84-108.

Dietrich, A. (2012). Explaining loan rate differentials between small and large companies: evidence from Switzerland. Small Business Economics, 38(4), 481-494. https://doi.org/10.1007/s11187-010-9273-8

Ebrahimi, P., \& Mirbargkar, S. M. (2017). Green entrepreneurship and green innovation for SME development in market turbulence. Eurasian Business Review, 7(2), 203-228. https://doi.org/10.1007/s40821-017-0073-9

EC. (2016). Small and Medium Sized Enterprises Access to Finance. European Semester Thematic Factsheet. Retrieved from https://ec.europa.eu/info/sites/info/files/file_import/european-semester_thematicfactsheet_small-medium-enterprises-access-finance_en.pdf

Egels-Zandén, N. (2017). The role of SMEs in global production networks: A Swedish SME's payment of living wages at its Indian supplier. Business \& Society, 56(1), 92-129. https://doi.org/10.1177/0007650315575107

Ellegaard, C. (2006). The small company purchasing: A research agenda. Journal of Purchasing and Supply Management, 12(5), 272-283. https://doi.org/10.1016/j.pursup.2006.08.004

Eniola, A. A., \& Entebang, H. (2017). SME Managers and Financial Literacy. Global Business Review, 18(3), 559-576. https://doi.org/10.1177/0972150917692063

Falkner, E. M., \& Hiebl, M. R. W. (2015). Risk management in SMEs: a systematic review of available evidence. The Journal of Risk Finance, 16(2), 122-144. https://doi.org/10.1108/JRF-06-2014-0079

Ghobakhloo, M., Hong, T. S., Sabouri, M. S., \& Zulkifli, N. (2012). Strategies for Successful Information Technology Adoption in Small and Medium-sized Enterprises. Information, 3(1), 36-67. https://doi.org/10.3390/info3010036

Halim, H. A., Ahmad, N. H., Ramayah, T., \& Hanifah, H. (2014). The growth of innovative performance among SMEs: Leveraging on organizational culture and innovative 
human capital. Journal of Small Business and Entrepreneurship Development, 2(1), 107-125.

Hall, B., Lotti, F., \& Mairesse, J. (2009). Innovation and Productivity in SMEs. Empirical Evidence for Italy *. Small Business Economics, 33(1), 13-33. https://doi.org/10.2139/ssrn.1523220

Handfield, R. B., \& Bechtel, C. (2002). The role of trust and relationship structure in improving supply chain responsiveness. Industrial Marketing Management, 31(4), 367-382. https://doi.org/10.1016/S0019-8501(01)00169-9

Hashim, M. J., Osman, I., \& Alhabshi, S. M. (2015). Effect of Intellectual Capital on Organizational Performance. Procedia - Social and Behavioral Sciences, 211, 207-214. https://doi.org/10.1016/j.sbspro.2015.11.085

Hassan, M. U., Iqbal, Z., Malik, M., \& Ahmad, M. I. (2017). Exploring the role of technological developments and open innovation in the survival of SMEs: an empirical study of Pakistan. International Journal of Business Forecasting and Marketing Intelligence, 4(1), 64-85. https://doi.org/10.1504/IJBFMI.2018.088629

Hussain, I., Farooq, Z., \& Akhtar, W. (2012). SMEs development and failure avoidance in developing countries through public private partnership. African Journal of Business Management, 6(4), 1581-1589. https://doi.org/10.5897/AJBM11.2526

Hussain, I., Si, S., Xie, X. M., \& Wang, L. (2010). Comparative Study on Impact of Internal and External CFFs on SMEs. Journal of Small Business \& Entrepreneurship, 23(4), 637-648. https://doi.org/10.1080/08276331.2010.10593506

Hussin, H., King, M., \& Cragg, P. (2002). IT alignment in small firms. European Journal of Information Systems, 11(2), 108-127. https://doi.org/10.1057/palgrave.ejis.3000422

Hyder, S., \& Lussier, R. N. (2016). Why businesses succeed or fail: a study on small businesses in Pakistan. Journal of Entrepreneurship in Emerging Economies, 8(1), 82-100. https://doi.org/10.1108/JEEE-03-2015-0020

IFC. (2009). The SME Banking Knowledge Guide (2nd ed.). Washington: The World Bank Group. Retrieved from https://www.ifc.org/wps/wcm/connect/b4f9be0049585ff9a192b519583b6d16/SM EE.pdf?MOD=AJPERES

Igbaria, M., Zinatelli, N., Cragg, P., \& Cavaye, A. L. M. (1997). Personal Computing Acceptance Factors in Small Firms: A Structural Equation Model. MIS Quarterly, 21(3), 279-305. https://doi.org/10.2307/249498

Imran, M., Hamid, S. N. binti A., \& Aziz, A. binti. (2018). The influence of TQM on export performance of SMEs: Empirical evidence from the manufacturing sector in Pakistan using PLS-SEM. Management Science Letters, 8, 483-496. https://doi.org/10.5267/j.msl.2018.3.003

Islam, M. A., Khan, M. A., Obaidullah, A. Z. M., \& Alam, M. S. (2011). Effect of Entrepreneur and Firm Characteristics on the Business Success of Small and Medium Enterprises (SMEs) in Bangladesh. International Journal of Business and Management, 6(3), 289-299.

Jasra, J. M., Hunjra, A. I., Rehman, A. U., Azam, R. I., \& Khan, M. A. (2011). Determinants of business success of small and medium enterprises. International Journal of Business and Social Science, 2(20), 274-280.

Jebna, A. K. K., \& Baharudin, A. S. (2013). Factors Affecting Small and Medium Enterprises Success: An Exploratory Study. Jurnal Teknologi, 64(3), 69-72. https://doi.org/10.11113/jt.v64.2272 
Johnsen, T. E. (2009). Supplier involvement in new product development and innovation: Taking stock and looking to the future. Journal of Purchasing and Supply Management, 15(3), 187-197. https://doi.org/10.1016/j.pursup.2009.03.008

Jutla, D., Bodorik, P., \& Dhaliwal, J. (2002). Supporting the e-business readiness of small and medium-sized enterprises: approaches and metrics. Internet Research, 12(2), 139-164. https://doi.org/10.1108/10662240210422512

Kaya, D., \& Koch, M. (2015). Countries' adoption of the International Financial Reporting Standard for Small and Medium-sized Entities (IFRS for SMEs) - early empirical evidence. Accounting and Business Research, 45(1), 93-120. https://doi.org/10.1080/00014788.2014.969188

Khalique, M. (2011). Do Malaysia and Pakistan are suitable for a comparative study of SMEs: an intellectual capital perspective? Interdisciplinary Journal of Contemporary Research in Business, 3(8), 98-107.

Khalique, M., Bontis, N., Shaari, J. A. N. bin, \& Isa, A. H. M. (2015). Intellectual capital in small and medium enterprises in Pakistan. Journal of Intellectual Capital, 16(1), 224-238. https://doi.org/10.1108/JIC-01-2014-0014

Khalique, M., Isa, A. H. B. M., \& Shaari, J. A. N. (2011). Challenges for Pakistani SMEs in a knowledge-based economy. Indus Journal of Management \& Social Sciences, 5(2), 74-80.

Khoumbati, K., Themistocleous, M., \& Irani, Z. (2006). Evaluating the Adoption of Enterprise Application Integration in Health-Care Organizations. Journal of Management Information Systems, 22(4), 69-108. https://doi.org/10.2753/MIS0742-1222220404

Kitching, J., Hart, M., \& Wilson, N. (2015). Burden or benefit? Regulation as a dynamic influence on small business performance. International Small Business Journal, 33(2), 130-147. https://doi.org/10.1177/0266242613493454

Knudsen, J. S. (2013). The Growth of Private Regulation of Labor Standards in Global Supply Chains: Mission Impossible for Western Small- and Medium-Sized Firms? Journal of Business Ethics, 117(2), 387-398. https://doi.org/10.1007/s10551012-1527-8

Krasniqi, B. A. (2007). Barriers to entrepreneurship and sme growth in transition: the case of kosova. Journal of Developmental Entrepreneurship, 12(01), 71-94. https://doi.org/10.1142/S1084946707000563

Li, D., Lai, F., \& Wang, J. (2010). E-Business Assimilation in China's International Trade Firms: The Technology-organization Environment Framework. Journal of Global Information Management, 18(1), 15-38. https://doi.org/10.4018/jgim.2010091102

Love, J. H., \& Roper, S. (2015). SME innovation, exporting and growth: A review of existing evidence

SME innovation, exporting and growth: A review of existing evidence. International Small Business Journal, 33(1), 28-48. https://doi.org/10.1177/0266242614550190

Lund-Thomsen, P. (2013). Labor agency in the football manufacturing industry of Sialkot, Pakistan. Geoforum, 44, 71-81. https://doi.org/10.1016/j.geoforum.2012.04.007

Luoma-aho, V., Vos, M., Lappalainen, R., Lämsä, A.-M., Uusitalo, O., Maaranen, P., \& Koski, A. (2012). Added Value of Intangibles for Organizational Innovation. Human Technology An Interdisciplinary Journal On Humans In ICT Environments, 8(1), 7-23. https://doi.org/10.17011/ht/urn.201205141650

MacGregor, R. C., \& Vrazalic, L. (2005). A basic model of electronic commerce adoption barriers: A study of regional small businesses in Sweden and Australia. Journal 
of Small Business and Enterprise Development, 12(4), 510-527. https://doi.org/10.1108/14626000510628199

Mahmood, Z., Kouser, R., Hasan, I., \& Iqbal, Z. (2017). Why Pakistani Small and Medium Enterprises are Not Reporting on Sustainability Practices? Pakistan Journal of Commerce and Social Sciences, 11(1), 389-405.

Marri, H. B., Gunasekaran, A., Gopang, M. A., Nebhwani, M., \& Soomro, A. S. (2017). Assessment of CIM implementation in SMEs: a multiple case study approach. The International Journal of Advanced Manufacturing Technology, 90(5-8), 2193-2206. https://doi.org/10.1007/s00170-016-9543-y

Martin, L. M., \& Matlay, H. (2001). "Blanket" approaches to promoting ICT in small firms: some lessons from the DTI ladder adoption model in the UK. Internet Research, 11(5), 399-410. https://doi.org/10.1108/EUM0000000006118

Matsoso, M. L., \& Benedict, O. H. (2014). The customer-supplier relationships in supply chain management: $A$ small manufacturing enterprise (SME) perspective. Journal of Economics, 5(2), 177-184.

Melville, N., \& Ramirez, R. (2008). Information technology innovation diffusion: an information requirements paradigm. Information Systems Journal, 18(3), 247273. https://doi.org/10.1111/j.1365-2575.2007.00260.x

Memon, S., Rohra, C. L., \& Lal, P. (2010). Critical analysis of the performance management system (pms) in SMEs of Karachi. Australian Journal of Basic and Applied Sciences, 4(6), 1495-1503.

Morrissey, W. J., \& Pittaway, L. (2006). Buyer-Supplier Relationships in Small Firms Buyer-Supplier Relationships in Small Firms: The Use of Social Factors to Manage Relationships, The Use of Social Factors to Manage Relationships. International Small Business Journal, 24(3), 272-298. https://doi.org/10.1177/0266242606063433

Mubarak, M. S., Chandran, V. G. R., \& Devadason, E. S. (2018). Measuring Human Capital in Small and Medium Manufacturing Enterprises: What Matters? Social Indicators Research, 137(2), 605-623. https://doi.org/10.1007/s11205-017-16019

Nichter, S., \& Goldmark, L. (2009). Small Firm Growth in Developing Countries. World Development, 37(9), 1453-1464. https://doi.org/10.1016/j.worlddev.2009.01.013

Nieto, M. J., \& Santamaría, L. (2010). Technological Collaboration: Bridging the Innovation Gap between Small and Large Firms*. Journal of Small Business Management, 48(1), 44-69. https://doi.org/10.1111/j.1540-627X.2009.00286.x

Nooteboom, B. (1994). Innovation and diffusion in small firms: Theory and evidence. Small Business Economics, 6(5), 327-347. https://doi.org/10.1007/BF01065137

OECD. (2014). Small Businesses, Job Creation, and Growth: Facts, Obstacles, and Best Practices. The OECD Publication.

Omer, M. M. (2015). Marketing Communication through Social Media: A Exploratory Case Study of SME's in Pakistan. Arabian Journal of Business and Management Review, 5(5), 1-3. https://doi.org/10.4172/2223-5833.1000141

Page, J., \& Söderbom, M. (2015). Is Small Beautiful? Small Enterprise, Aid and Employment in Africa - Page - 2015 - African Development Review - Wiley Online Library. African Development Review, 27(1), 44-55. https://doi.org/10.1111/1467-8268.12138

Pan, M.-J., \& Jang, W.-Y. (2008). Determinants of the Adoption of Enterprise Resource Planning within the Technology-Organization-Environment Framework: Taiwan's Communications Industry. Journal of Computer Information Systems, 48(3), 94- 
102. https://doi.org/10.1080/08874417.2008.11646025

Parežanin, M., Jednak, S., \& Kragulj, D. (2014). The Influence of the Knowledge-Based Economy on the Competitiveness of European Economies and Businesses. In Innovative Management and Firm Performance (pp. 68-90). Palgrave Macmillan, London. https://doi.org/10.1057/9781137402226_3

Pathan, Z. H., Tunio, M. Z., Latif, Z., Ahmed, S., \& Naich, S. u R. (2018). Empirical Analysis of ICT Constraints Affect the Performance of Small \& Medium Enterprises in Pakistan. Saudi Journal of Engineering and Technology (SJEAT), 3(1), 1-9. https://doi.org/10.21276/sjeat.2018.3.1.1

Pathan, Z. H., Jianqiu, Z., Akram, U., Khan, M. K., Latif, Z., \& Tunio, M. Z. (2017). Research on ICT Patterns and Integration in Small \& Medium Enterprises" A Case Study of Pakistan". International Journal of $U$ - and e- Service, Science, and Technology, 10(2), 53-64. http://dx.doi.org/10.14257/ijunesst.2017.10.2.06

Petković, S., Jäger, C., \& Sašić, B. (2016). Challenges of small and medium-sized companies at an early stage of development: Insights from Bosnia and Herzegovina. Management: Journal of Contemporary Management Issues, 21(2), 45-76.

Pressey, A. D., Winklhofer, H. M., \& Tzokas, N. X. (2009). Purchasing practices in smallto medium-sized enterprises: An examination of strategic purchasing adoption, supplier evaluation, and supplier capabilities. Journal of Purchasing and Supply Management, 15(4), 214-226. https://doi.org/10.1016/j.pursup.2009.03.006

Quader, S. M., \& Abdullah, M. N. (2008). Constraints to SMEs: A Rotated Factor Analysis Approach. MPRA Paper, 26135, 1-22.

Rehman, N. U. (2016). Network alliances and firms' performance: a panel data analysis of Pakistani SMEs. Eurasian Business Review, 6(1), 37-52. https://doi.org/10.1007/s40821-015-0033-1

Ritchie, B., \& Brindley, C. (2005). ICT adoption by SMEs: implications for relationships and management. New Technology, Work, and Employment, 20(3), 205-217.

Rodríguez, A., \& Nieto, M. J. (2016). Does R\&D offshoring lead to SME growth? Different governance modes and the mediating role of innovation. Strategic Management Journal, 37(8), 1734-1753. https://doi.org/10.1002/smj.2413

Saridakis, G., Lai, Y., Muñoz Torres, R. I., \& Mohammed, A.-M. (2017). Actual and intended growth in family firms and non-family-owned firms: are they different? Journal of Organizational Effectiveness: People and Performance, 5(1), 2-21. https://doi.org/10.1108/JOEPP-04-2017-0033

Seethamraju, R. (2015). Adoption of Software as a Service (SaaS) Enterprise Resource Planning (ERP) Systems in Small and Medium Sized Enterprises (SMEs). Information Systems Frontiers, 17(3), 475-492. https://doi.org/10.1007/s10796014-9506-5

Selamat, Z., Jaffar, N., \& Kadir, H. A. (2011). ICT adoption in Malaysian SMEs. In Proc. of International Conference on Management and Service Science (Vol. 8, pp. 135-139). Singapore: IPEDR.

Sherazi, S. K., Iqbal, M. Z., Asif, M., Rehman, K., \& Shah, S. H. (2013). Obstacles to Small and Medium Enterprises in Pakistan. Principal Component Analysis Approach. Middle-East Journal of Scientific Research, 13(10), 1325-1334.

Singh, R. K., Garg, S. K., \& Deshmukh, S. G. (2009). The competitiveness of SMEs in a globalized economy: Observations from China and India. Management Research Review, 33(1), 54-65. https://doi.org/10.1108/01409171011011562

SMEDA. (2007). SME Policy Development. Retrieved August 4, 2018, from 
https://smeda.org/index.php?option=com_content\&view=article\&id=58:smepolicy-development\&catid=2\&Itemid=101

Stuart, T. E. (2000). Interorganizational alliances and the performance of firms: a study of growth and innovation rates in a high-technology industry. Strategic Management Journal, 21(8), $\quad$ 791-811. $\quad$ https://doi.org/10.1002/10970266(200008)21:8<791::AID-SMJ121>3.0.CO;2-K

Swierczek, F. W., \& Ha, T. T. (2003). Entrepreneurial Orientation, Uncertainty Avoidance and Firm Performance,

Entrepreneurial Orientation, Uncertainty Avoidance and Firm Performance: An Analysis of Thai and Vietnamese SMEs, An Analysis of Thai and Vietnamese SMEs. The International Journal of Entrepreneurship and Innovation, 4(1), 46-58. https://doi.org/10.5367/000000003101299393

Teo, T. S. H. (2001). Demographic and motivation variables associated with Internet usage activities. Internet Research, 11(2), 125-137. https://doi.org/10.1108/10662240110695089

Ullah, B., Aziz, A., \& Yousaf, M. H. (2016). IC in SMEs in Pakistan. Global Journal of Management And Business Research, 15(11), 41-48.

Ullah, M. S., Naimi, N. B., \& Yusoff, R. B. M. (2016). Are Small and Medium Enterprises (SMEs) in Lahore Failing at the Rate Suggested in Prior Studies? An Analysis of the Degree of Financial Stress on Small and Medium Enterprises and its Impact on their Life Expectancy. International Business Management, 10(18), 42584267.

Verhees, F. J. H. M., \& Meulenberg, M. T. G. (2004). Market Orientation, Innovativeness, Product Innovation, and Performance in Small Firms. Journal of Small Business Management, 42(2), 134-154. https://doi.org/10.1111/j.1540-627X.2004.00102.x

Weston, J. P., \& Strahan, P. E. (1996). Small Business Lending and Bank Consolidation: Is There Cause for Concern? Current Issues in Economics and Finance, 2(3), 16. https://doi.org/10.2139/ssrn.1001240

World Bank. (2009). Ch4: Bringing Finance to Pakistan's Poor.pdf (pp. 59-74). The World Bank Publication.

Zafar, A., \& Mustafa, S. (2017). SMEs and its role in the economic and socio-economic development of Pakistan. International Journal of Academic Research in Economics and Management Sciences, 6(4), 1-16. 
